\title{
STUDI KASUS PENERAPAN KONSEP BIAYA RELEVAN DALAM KEPUTUSAN DISKON HARGA PUPUK NPK
}

\author{
Eny Rachmawati \\ Universitas Mayjen Sungkono Mojokerto \\ Email: Enyrachmawati96@gmail.com
}

\begin{abstract}
Research actually aim the information on the maximum limit of discount given problem encountered by pupuk organik industries is the lack of information on the relevan cost dealing with the decision making on giving the discoun. The obyective of the case study is to supply the information on the maximum limit of the discount given. The method includes the use of relevant cost concept. The data analysis of the cost with the stages :(1) Classifing the cost based on itsbehaviours to know the fixed cost, the variable and semi variable one, (2) Determining fixed and variable elememt in semi variable cost by using least squares method, (3) Calculating variable cost per unit, and (4) Calculating the percentage of maximum discount is as much as contributionmargin per unit Rp. 8.281,55 of normal selling priceRp. 25.000,- or as much as contribution margin ratio 33, $13 \%$ and minimum selling price is as much as Rp. 16.718,55 per unit
\end{abstract}

\section{Keywords : relevan cost, selling price discount, contribusi margin}

\section{ABSTRAK}

Penelitian ini bertujuan untuk memberikan informasi tentang batas maksimum diskon yang dapat diberikan karena belum tersedianya informasi biaya yang relevan dengan pengambilan putusan diskon. Berkenaan dengan hal tersebut maka penelitian ini membuktikan secara empiris penggunaan konsep biaya relevan, pengolahan data biaya dan tingkat kegiatan : 1. Pengklasifikasian biaya berdasarkan perilakunya untuk mengetahui biaya tetap, biaya variabel dan biaya semi variabel 2. Penentuan unsur tetap dan unsur variabel dalam biaya semi variabel metode kuadrat terkecil 3. Penghitungan biaya variabel per unit 4 . Penghitungan persentase potong maksimal harga jual normal dan harga jual per unit. Hasil studi kasus berupa diskon maksimal sebesar margin kontribusi per unit Rp. 8.281,55,- dari harga jual normal Rp. 25.000,- per unit atau sebesar contribution margin ratio 33,13\% sehingga harga jual minimal Rp. $16.718,55$ per unit

\section{Kata kunci : Biaya relevan, Keputusan discont, marjin kontribusi}

PENDAHULUAN

Pada dasarnya, suatu perusahaan

baik yang bergerak di bidang jasa, manufaktur maupun, dagang menjalankan kegiatan operasionalnya untuk mencapai suatu tujuan, salah satunya yaitu 
mempertahankan kelangsungan hidup perusahaan dan mencapai laba semaksimal mungkin.Banyak industri kecil dan menengah yang masih belum berani memberikan diskon untuk pesanan yang diterima,sehingga berakibat hilangnya kesempatan untuk memperoleh tambahan keuntungan.

Kurang beraninya memberikan keputusan diskon seringkali disebabkan kurangnya pengetahuan tentang perilaku biaya dan konsep biaya relevan.Perilaku biaya pada dasarnya adalah hubungan antara jumlah biaya dengan perubahan tingkat kegiatan. Bila suatu biaya jumlahnya tetap dan tidak dipengaruhi oleh perubahan tingkat kegiatan dalam kisaran tertentu disebut dengan biaya tetap. Sedangkan bila jumlahnya berubah dan perubahannya proposional dengan tingkat kegiatan merupakan biaya variabel. Sedangkan biaya yang mempunyai unsur tetap dan unsur variabel disebut dengan biaya semi variabel.Pengetahuan tentang perilaku biaya yang terjadi dan menjadi beban perusahaan akan memberikan informasi bagi manajemen yang berguna bagi pengambilan keputusan untuk menerima atau menolak pesanan dengan harga di bawah harga normal.

Biaya relevan merupakan biaya yang patut dipertimbangkan dalam pengambilan keputusan. Pada dasarnya biaya relevan adalah biaya yang akan berbeda jumlahnya di antara dua alternative atau lebih. Menurut Hongren (2008) biaya relevanadalah biaya yang akan terjadi dimasa yang datang dan berbeda diantara alternatif yang sedang dipertimbangkan di dalam suatu keputusan sedangkan menurut Mulyadi (2009) Suatu biaya yang jumlahnya akan berbeda diantara dua alternatif atau lebih pada umumnya yaitu biaya variabel, tetapi tidak selalu biaya tetap bukan merupakan biaya relevan, karena biaya tetap juga dapat berubah jumlahnya bila telah melampui kisaran tertentu. Untuk membantu memberikan informasi biaya yang relevan dalam pengambilan keputusan manajemen sangat diperlukan klasifikasi biaya berdasarkan perilakunya, dan selanjutnya biaya perlu ditentukan jumlah biaya variabel dan biaya tetapnya.

Pada dasarnya, tingkat kegiatan perusahaan mencapai kapasitas normal berarti kegiatan belum mencapai tingkat kapasitas maksimum, sehingga perusahaan masih mampu melayani pesanan tambahan tanpa mempengaruhi jumlah biaya tetapnya. Bila tambahan biaya yang akan bertambah yaitu biaya variabel saja. Diskon yang dapat memberikan tambahan keuntungan harus lebih kecil dari margin kontribusi, maka akan mendatangkan keuntungan bagi perusahaaan. Apabila ternyata pesanan tambahan dapat menghasilkan laba sedangkan harga jualnya 
masih dibawah harga normal, maka menurut pengetahuan tentang perilaku biaya dan konsep biaya relevan, pesanan tambahan tersebut dapat diterima karena dapat mendatangkan keuntungan.

\section{METODE PENELITIAN}

\section{Jenis penelitian}

Penelitian ini bertujuan untuk mengetahui dan menggambarkan keadaan yang sesungguhnya terjadi dengan setepat mungkin. Dengan demikian, penelitian yang dilakukan ini adalah penelitian deskriptif dengan pendekatan studi kasus.

Dalam metode diskriptif menggunakan pendekatan studi kasus karena penelitian ini dilakukan pada jumlah unit yang kecil sehingga memungkinkan adanya analisis yang mendalam.

\section{Sumber Data}

Berdasarkan sumbernya, maka data dalam penelitian yakni: data sekunder yang berupa data biaya dan data produksi perusahaan yang menjadi obyek penelitian dan studi pustaka yang meliputi data yang berasal dari laporan hasil penelitian.

\section{Analisis Data}

Analisis data dalam penelitian ini merupakan penerapan analisis kuntitatif dari informasi serta data CV Putra Pertiwi selama bulan 2011-2015 dengan analisis kuantitatif sebagai berikut:

1. Menggolongkan biaya tetap, biaya variabel dan biaya semi variabel.
Untuk membantu memberikan informasi biaya yang relevan dalam pengambilan keputusan manajemen, sangat diperlukan klasifikasi biaya berdasarkan perilakunya dan selanjutnya biaya perlu ditentukan jumlah biaya tetap dan variabelnya. Berdasarkan perilakunya biaya dibedakan menjadi biaya variabel, biaya tetap dan biaya semi variabel.

2. Pemisahan biaya semi variabel.

Pada metode kuadrat terkecil (least square method) ini dinyatakan bahwa hubungan antara biaya dengan volume kegiatan berbentuk hubungan garis lurus persamaan garis regresi $\mathrm{y}=\mathrm{a}+\mathrm{bx}$. Rumus perhitungan $a$ dan $b$ adalah sebagai berikut:

$$
b=\frac{n \cdot \sum x y-\sum x \cdot \sum y}{n \cdot \sum x^{2}-\left(\sum x\right)^{2}}
$$

$$
a=\frac{\sum y-b \cdot \sum x}{n}
$$

Rumus tersebut digunakan untuk mendapatkan unsur biaya tetap dan biaya variabel yang terdapat pada biaya semivariabel. Dimana y merupakan variabel tidak bebas (terikat) yang ditentukan oleh variabel x. Variabel y menunjukkan biaya (total biaya), sedangkan variabel $\mathrm{x}$ menunjukkan volume kegiatan. Di dalam persamaan tersebut, a menunjukkan unsur biaya tetap dan $b$ menunjukkan unsur biaya variabel.

3. Menentukan biaya relevan. 
Dengan mengklasifikasikan biaya berdasarkan perilaku dan identifikasi biaya semi variabel ke dalam unsur tetap dan variabel dapat diketahui jumlah total biaya variabel dan biaya variabel per unit. Biaya relevan merupakan biaya yang patut diperhitungkan dalam pengambilan keputusan. Karena biaya variabel tersebut akan berubah jumlahnya dengan adanya pesanan tambahan atas penjualan.

4. Diskon atau potongan maksimum

Bila tambahan masih dapat dilayani dengan memanfaatkan kapasitas menganggur, maka biaya yang akan bertambah yaitu biaya variabel saja. Dengan demikian harga jual minimal atas tambahan penjualan yaitu sebesar biaya variabel.Harga jual minimal sebesar biaya variabel per unit. Sedangkan diskon maksimal sebesar marjin kontribusi per unit. Perhitungan potongan maksimum atas harga jual normal dengan rumus:
Contribution Margin Ratio (CMR) = (CM/TR x100\%)

Atau Diskon maksimum per unit sebesar

Contribution Margin $=\mathrm{P}-\mathrm{VC}$

Dengan

CMR : Contribution margin ratio

$\mathrm{CM}$ : Contribution margin

TR : Total revenue

$\mathrm{P}$ : Price/unit

$\mathrm{VC}:$ Variable cost/unit

\section{HASIL DAN PEMBAHASAN}

\section{Klasifikasi Biaya Berdasarkan \\ Perilakunya}

a. Biaya Tetap

Biaya yang secara total tetap dan tidak dipengaruhi dengan perubahan tingkat kegiatan termasuk biaya tetap. Berdasarkan datayang diperoleh, maka tabel 1 menunjukkan biaya tetap.

Tabel 1 Klasifikasi Biaya Tetap

\begin{tabular}{|c|c|c|c|c|c|c|}
\hline \\
\hline No & NAMA BIAYA & $\begin{array}{c}2011 \\
(\mathrm{x} 1000)\end{array}$ & $\begin{array}{c}2012 \\
(\mathrm{x} 1000)\end{array}$ & $\begin{array}{c}2013 \\
(\mathrm{x} 1000)\end{array}$ & $\begin{array}{c}2014 \\
(\mathrm{x} 1000)\end{array}$ & $\begin{array}{c}2015 \\
(\mathrm{x} 1000)\end{array}$ \\
\hline 1 & $\begin{array}{l}\text { Biaya Tenaga Kerja Tak } \\
\text { Langsung }\end{array}$ & 105.200 & 105.200 & 105.200 & 105.200 & 105.200 \\
\hline 2 & $\begin{array}{l}\text { Biaya perawatan Peralatan dan } \\
\text { Gedung }\end{array}$ & 6.500 & 6.500 & 6.500 & 6.655 & 6.655 \\
\hline 3 & Biaya Penyusutan Mesin & 22.000 & 22.000 & 22.000 & 22.000 & 22.000 \\
\hline 4 & $\begin{array}{l}\text { Biaya Penyusutan Gedung } \\
\text { Pabrik }\end{array}$ & 35.300 & 35.300 & 35.300 & 35.300 & 35.300 \\
\hline 5 & $\begin{array}{l}\text { Biaya Asuransi Bagian } \\
\text { Produksi }\end{array}$ & 11.200 & 11.200 & 11.200 & 11.200 & 11.200 \\
\hline 6 & Biaya Gaji Bagian Penjualan & 42.400 & 42.400 & 42.400 & 42.400 & 42.400 \\
\hline 7 & $\begin{array}{l}\text { Biaya Gaji Administrasi dan } \\
\text { Umum }\end{array}$ & 208.300 & 208.300 & 208.300 & 208.300 & 208.300 \\
\hline 8 & $\begin{array}{l}\text { Biaya Penyusutan Kendaraan } \\
\text { Kantor }\end{array}$ & 38.200 & 38.200 & 38.200 & 838.200 & 3.200 \\
\hline 9 & $\begin{array}{l}\text { Biaya Penyusutan Gedung } \\
\text { Kantor }\end{array}$ & 25.700 & 25.700 & 25.700 & 25.700 & 25.700 \\
\hline
\end{tabular}




\begin{tabular}{|c|l|r|r|r|r|r|}
\hline 10 & $\begin{array}{l}\text { Biaya Penyusutan Peralatan } \\
\text { Kantor }\end{array}$ & 12.000 & 12.000 & 12.000 & 12.000 & 12.000 \\
\hline 11 & $\begin{array}{l}\text { Biaya Asuransi Bag. } \\
\text { Administrasi dan Umum }\end{array}$ & 11.800 & 11.800 & 11.800 & 11.800 & 11.800 \\
\hline 12 & Biaya THR & 27.000 & 27.000 & 27.000 & 27.000 & 27.000 \\
\hline & TOTAL BIAYA & 545.600 & 545.600 & 545.600 & 545.600 & 545.600 \\
\hline & PRODUKSI/PENJUALAN & 200 & 206 & 210 & 216 & 220 \\
\hline
\end{tabular}

b. Biaya Variabel

perubahan tingkat kegiatan yaitu biaya

Biaya yang secara total berubah dan perubahannya proporsional dengan variabel, sehingga biaya variabel per unitnya adalah tetap.

Tabel 2 Klasifikasi Biaya Variabel

\begin{tabular}{|c|l|c|c|c|c|c|}
\hline No & \multicolumn{1}{|c|}{ NAMA BIAYA } & $\begin{array}{c}2011 \\
(\mathrm{x} \mathrm{1000)}\end{array}$ & $\begin{array}{c}2012 \\
(\mathrm{x} 1000)\end{array}$ & $\begin{array}{c}2013 \\
(\mathrm{x} 1000)\end{array}$ & $\begin{array}{c}2014 \\
(\mathrm{x} 1000)\end{array}$ & $\begin{array}{c}2015 \\
(\mathrm{x} 1000)\end{array}$ \\
\hline 1 & Biaya Bahan Baku & 1.667 .000 & 1.669 .000 & 1.740 .000 & 1.780 .000 & 1.920 .000 \\
\hline 2 & $\begin{array}{l}\text { Biaya Tenaga Kerja } \\
\text { Langsung }\end{array}$ & 1.380 .000 & 1.395 .000 & 1.420 .000 & 1.445 .000 & 1.457 .000 \\
\hline 3 & Biaya Bahan Penolong & 111.800 & 116.800 & 118.300 & 126.900 & 128.800 \\
\hline 4 & Biaya Solar Mesin & 27.900 & 29.000 & 29.500 & 30.900 & 35.600 \\
\hline 5 & $\begin{array}{l}\text { Biaya Pengepakan dan } \\
\text { Pengiriman }\end{array}$ & 48.400 & 48.900 & 50.300 & 51.900 & 53.400 \\
\hline 6 & Biaya Komisi Penjualan & 17.300 & 18.300 & 18.200 & 19.400 & 22.600 \\
\hline 7 & Biaya Penagihan & 3.000 & 3.300 & 3.500 & 3.650 & 3.700 \\
\hline & TOTAL BIAYA & 3.255 .400 & 3.280 .300 & 3.379 .800 & 3.457 .750 & 3.621 .100 \\
\hline & PRODUKSI/PENJUALAN & 200 & 206 & 210 & 216 & 220 \\
\hline & $\begin{array}{l}\text { BIAYA } \\
\text { VARIABEL/UNIT }\end{array}$ & 16.277 & 15.923 & 16.094 & 16.008 & 16.459 \\
\hline
\end{tabular}

c. Biaya Semi Variabel

proporsional dengan perubahan tingkat

Sedangkan biaya semi variabel secara total kegiatan.

berubah. Namun, perubahan tidak

Tabel 3 Klasifikasi Biaya Semi Variabel

\begin{tabular}{|c|c|c|c|c|c|c|}
\hline No & NAMA BIAYA & $\begin{array}{c}2011 \\
(\mathrm{x} 1000)\end{array}$ & $\begin{array}{c}2012 \\
(\mathrm{x} 1000)\end{array}$ & $\begin{array}{c}2013 \\
(\mathrm{x} 1000)\end{array}$ & $\begin{array}{c}2014 \\
(\times 1000)\end{array}$ & $\begin{array}{c}2015 \\
(x \quad 1000)\end{array}$ \\
\hline 1 & Biaya Listrik dan Air & 28.000 & 28.898 & 28.900 & 28.870 & 29.900 \\
\hline 2 & Biaya Pemeliharaan Suku Cadang & 1.536 & 1.544 & 1.558 & 1.593 & 1.597 \\
\hline 3 & Biaya Iklan & 18.500 & 18.729 & 18.805 & 19.300 & 19.998 \\
\hline 4 & Biaya Telepon Bag. Pemasaran & 14.460 & 14.449 & 14.589 & 15.036 & 15.770 \\
\hline 5 & Biaya Perawatan Gedung Kantor & 10.114 & 10.269 & 10.366 & 10.561 & 10.884 \\
\hline 6 & Biaya Listrik dan Air Kantor & 14.567 & 13.549 & 13.600 & 13.900 & 14.000 \\
\hline \multirow[t]{3}{*}{7} & Biaya Lain-lain & 6.200 & 6.550 & 6.700 & 6.748 & 6.788 \\
\hline & TOTAL BIAYA & 93.377 & 93.988 & 94.518 & 96.008 & 98.937 \\
\hline & PRODUKSI/PENJUALAN & 200 & 206 & 210 & 216 & 220 \\
\hline
\end{tabular}

Identifikasi Biaya Semi Variable ke Untuk kepentingan analisis biaya relevan, dalam Unsur Tetap dan Variabel klasifikasi biaya berdasarkan perilakunya hanya dibutuhkan data biaya tetap secara 
total dan biaya variabel saja. Oleh

variabel harus diidentifikasikan unsur tetap karenanya total biaya yang bersifat semi dan variabel.

Tabel 4 Identifikasi Unsur Tetap dan Variabel dalam Total Biaya

\begin{tabular}{|c|c|c|c|c|}
\hline TAHUN & $Y(x$ 1000) & X (x 1000) & XY (x 1000) & $X^{2}(x$ 1000) \\
\hline 2011 & 93.377 & 200 & 18.675 .400 & 40.000 .000 \\
\hline 2012 & 93.988 & 206 & 19.361 .528 & 42.436 .000 \\
\hline 2013 & 94.518 & 210 & 19.848 .780 & 44.100 .000 \\
\hline 2014 & 96.008 & 216 & 20.737 .728 & 46.656 .000 \\
\hline 2015 & 98.937 & 220 & 21.766 .140 & 48.400 .000 \\
\hline $\mathrm{n}=5$ & 476.828 & 1.052 & 100.389 .576 & 221.592 .000 \\
\hline
\end{tabular}

$$
b=\frac{n \cdot \sum x y-\sum x \cdot \sum y}{n \cdot \sum x^{2}-\left(\sum x\right)^{2}}
$$

$b=\frac{5 x 100.389 .576 .000-1.052 .000 \times 476.828 .000}{5 x 221.592 .000 .000-(1.052 .000)^{2}}$

$5 \times 221.592 .000 .000-(1.052 .000)^{2}$

$b=\frac{501.947 .880 .000-501.623 .056 .000}{1.107 .960 .000 .000-1.106 .704 .000 .000}$

$b=\frac{324.824 .000 .000}{1.256 .000 .000}$

$b=259$

$a=\frac{\sum y-b \cdot \sum x}{n}$

$a=\frac{476.828 .000-259 \times 1.052 .000}{5}$

$a=\frac{476.828 .000-274.469 .000}{5}$
Berdasarkan analisis klasifikasi biaya berdasarkan perilakunya dan identifikasi unsur tetap dan unsur variabel dari total biaya semi variabel, maka:

Total biaya variabel $=259 \times 220.000$

$=\operatorname{Rp} 56.980 .000,-$

Sedangkan total biaya tetapnya yaitu Rp. 20.236.000,-

Tabel 5. Total Biaya Tetap (Biaya Tidak Relevan)

\begin{tabular}{|c|l|c|}
\hline No & \multicolumn{1}{|c|}{ NAMA BIAYA } & JUMLAH BIAYA \\
\hline 1 & Biaya Tenaga Kerja Tak Langsung & 105.200 .000 \\
\hline 2 & Biaya Perawatan Peralatan dan Gedung & 6.655 .000 \\
\hline 3 & Biaya Penyusutan Mesin & 22.000 .000 \\
\hline 4 & Biaya Penyusutan Gedung Pabrik & 35.300 .000 \\
\hline 5 & Biaya Asuransi Bagian Produksi & 11.200 .000 \\
\hline 6 & Biaya Gaji Bagian Penjualan & 42.400 .000 \\
\hline 7 & Biaya Gaji Administrasi Dan Umum & 208.300 .000 \\
\hline 8 & Biaya Penyusutan Kendaraan Kantor & 38.300 .000 \\
\hline 9 & Biaya Penyusutan Gedung Kantor & 25.700 .000 \\
\hline 10 & Biaya Penyusutan Peralatan Kantor & 12.200 .00 \\
\hline 11 & Biaya Asuransi Bagian Administrasi dan Umum & 11.800 .000 \\
\hline 12 & Biaya THR & 27.000 .000 \\
\hline 13 & Elemen Tetap dalam Biaya Semi Variabel & 20.236 .000 \\
\hline & TOTAL BIAYA & 565.836 .000 \\
\hline
\end{tabular}


Biaya tetap sebesar $\mathrm{Rp}$ 565.836.000,tersebut merupakan biaya yang tidak patut dipertimbangkan dalam pengambilan keputusan dengan adanya pesanan tambahan atas penjualan. Karena selama perusahaan masih mempunyai kapasitas menganggur biaya tetap tersebut tidak akan berubah jumlahnya.

\section{a. Biaya Relevan}

Demikian juga berdasarkan analisis data dengan mengklasifikasikan biaya berdasarkan perilaku dan identifikasi biaya semi variabel ke dalam unsur tetap dan variabel dapat diketahui jumlah total biaya variabel dan biaya variabel per unit pada kapasitas sebesar 220.000 unit. Pada tabel 6 menunjukkan biaya variabel (biaya relevan).

Tabel 6. Biaya Variabel (Biaya Relevan)

\begin{tabular}{|c|c|c|}
\hline No & NAMA BIAYA & $\begin{array}{l}\text { JUMLAH } \\
\text { BIAYA } \\
\end{array}$ \\
\hline 1 & Biaya Bahan Baku & 1.920 .000 .000 \\
\hline 2 & $\begin{array}{l}\text { Biaya Tanaga Kerja } \\
\text { Langsung }\end{array}$ & 1.457 .000 .000 \\
\hline 3 & Biaya Bahan Penolong & 128.800 .000 \\
\hline 4 & Biaya Solar Mesin & 35.600 .000 \\
\hline 5 & $\begin{array}{l}\text { Biaya Pengepakan dan } \\
\text { Pengiriman }\end{array}$ & 53.400 .000 \\
\hline 6 & $\begin{array}{l}\text { Biaya Komisi } \\
\text { Penjualan } \\
\end{array}$ & 22.600 .000 \\
\hline 7 & Biaya Penagihan & 3.700 .000 \\
\hline 8 & $\begin{array}{l}\text { Elemen variabel dalam } \\
\text { Biaya Semi Variabel }\end{array}$ & 56.980 .000 \\
\hline & TOTAL BIAYA & 3.678 .080 .000 \\
\hline & Biaya Variabel/unit & $16.718,55$ \\
\hline
\end{tabular}

Biaya variabel sebesar Rp 3.678.080.000,atau $\operatorname{Rp} 16.718,55$ per unit tersebut merupakan biaya relevan atau biaya yang perlu diperhitungkan dalam pengambilan keputusan. Karena biaya variabel tersebut akan berubah jumlahnya dengan adanya pesanan tambahan atas penjualan.

\section{Harga Jual Minimal / Potongan Maksimum atas Harga Jual Normal}

Berdasarkan konsep biaya relevan, maka harga jual atas tambahan penjualan ditetapkan dengan hanya mempertimbangkan tambahan biaya yang akan terjadi. Bila tambahan penjualan masih dapat dilayani dengan memanfaatkan kapasitas menganggur, maka biaya yang akan bertambah yaitu biaya variabel saja. Dengan demikian harga jual minimal atas tambahan penjualan yaitu sebesar biaya variabel yaitu Rp 16.718,55 per unit. Sedangkan diskon maksimal sebesar marjin kontribusi per unit dengan perhitungan menjadi.

Tabel 7 Perhitungan Marjin Kontribusi

\begin{tabular}{|l|l|l|}
\hline Harga Jual per unit & $\operatorname{Rp} 25.000,-$ & $100 \quad \%$ \\
\hline Total Biaya Variabel & $\operatorname{Rp} 16.718,55$ & $66,87 \%$ \\
\hline Marjin Kontribusi & $\operatorname{Rp} 8.281,45$ & $33,13 \%$ \\
\hline
\end{tabular}

Dengan demikian potongan maksimum yang dapat diberikan yaitu sebesar marjin kontribusi yaitu Rp 8.281,45 per unit. Marjin kontribusi sebesar Rp 8.281,45 per unit merupakan potongan maksimum, 
karena bila pesanan tambahan atas penjualan diberikan potongan melebihi marjin kontribusi, maka perusahaan akan menderita kerugian.

\section{Perhitungan Biaya dan Tambahan}

\section{Keuntungan dalam Keputusan Diskon}

Harga jual yang belum dapat menghasilkan tambahan keuntungan dan tidak mengakibatkan kerugian sebesar biaya variabel yaitu Rp 16.718,55 per unit. Harga jual dengan harapan dapat menghasilkan tambahan keuntungan sebesar $25 \%$ dari harga jual normal Rp 25.000,- yaitu sebesar Rp 6.250,- per unit.

Jadi harga jual dari tambahan order sebesar $\quad \operatorname{Rp} 22.968,55$ per unit. Dihitung dari:

Biaya variabel Rp 16.718,55

Tambahan keuntungan $\underline{R p \quad 6.250,00+}$

Harga jual tambahan Rp 22.968,55

Diskon yang diberikan kepada konsumen sebesar Rp 2.031,45 per unit. Dihitung dari:

Harga jual normal $\quad \operatorname{Rp} 25.000,00$

Harga jual tambahan $\underline{\operatorname{Rp} 22.968,55-}$

Diskon Rp 2.031,45

Tambahan keuntungan yang dapat diperoleh dengan adanya tambahan order adalah:

Rata-rata kapasitas normal tiap hari : 10 ton (2.000 unit).

Rata-rata kapasitas maksimal tiap hari : 12 ton ( 2.400 unit).
Rata-rata kapasitas menganggur tiap hari : 2 ton ( 400 unit).

Dikemas@5 kg.

Perusahaan akan mendapat tambahan keuntungan sebesar:

$(\operatorname{Rp} 22.968,55-\operatorname{Rp} 16.718,55) \times 400$ unit $=$ Rp 2.500.000,-

\section{Kesimpulan}

Biaya tetap tidak perlu dipertimbangkan dalam pengambilan keputusan karena jumlahnya tidak berubah. Biaya yang perlu diperhitungkan dan dipertimbangkan dalam pengambilan keputusan yaitu biaya variabel saja. Karena biaya variabel akan berubah jumlahnya dengan adanya pesanan tambahan atas penjualan. Harga jual yang belum dapat menghasilkan tambahan keuntungan dan tidak mengakibatkan kerugian sebesar biaya variabel. Diskon maksimal sebesar marjin kontribusi dari harga jual normal.Diskon yang dapat memberikan tambahan keuntungan harus lebih kecil dari marjin kontribusi (contribution margin).Dengan tambahan pesanan, keuntungan yang diperoleh perusahaan meningkat dan kontinuitas dapat terjamin di masa yang akan datang.Pesanan tersebut akan diterima dengan catatan tidak merusak harga pasar. 


\section{DAFTAR PUSTAKA}

Arikunto, Suharsini.2010. Prosedur Penelitian Suatu Pendekatan Praktek. Jakarta : Rineka Cipta Revisi 2010

Harnanto. 2004. Akuntansi Biaya: Untuk Perhitungan Harga Pokok Produk. Jakarta: Gramedia.

Hongren, Foster dan Datar. 2008. Akuntansi Biaya dengan Pendekatan Manajerial. Jakarta : Erlangga, anggota IKAPI.

Indriantoro, Nur dan Bambang Supomo. 2002 .Metodologi Penelitian Bisnis Untuk Akuntansi dan Manajemen. Edisi Pertama. Yogyakarta: BPFE

Kartadinata, Abas. 2000. Akuntansi dan Analisis Biaya: Suatu Pendekatan Terhadap Tingkah Laku Biaya.Jakarta:Rineka Cipta.

Kusnadi,dkk. 2002. Akuntansi Manajemen (Komprehensif, Tradisional dan Kontemporer). Malang : Universitas Brawijaya.

Mulyadi. 2009. Akuntansi Biaya Untuk Manajemen. Yogyakarta : Sekolah Tinggi Ilmu Menejemen YKPN.

Mulyadi. 2009. Akuntansi Biaya, Penentuan Harga Pokok dan Pengenalan Biaya Yogyakarta : Sekolah Tinggi YKPN.

Nazir, Mohammad. 2005. Metode Penelitian. Jakarta : Ghalia Indonesia.

Riyanto. 2004. Dasar-dasar Pembelanjaan Perusahaan. Yogyakarta : Gajah Mada University Press.

Sugiyono. 2004. Metode Penelitian Bisnis. Bandung: Alfa Beta.

Sugiri, Slamet dan Sulistiningsih. 2004. Akuntansi Menejemen Sebuah Pengantar. Yogyakarta: Sekolah Tinggi YKPN.

Supriyono, R.A. 2000. Akuntansi Biaya, Penentuan Harga dan Penetapan Harga Pokok. Yogyakarta: BPFE.

Usry - Mats. 2009. Akuntansi Biaya : Perencanaan dan Pengendalian. Jakarta: Salemba Empat. 